\title{
REAKSI SIGNAL FAKTOR MAKROEKONOMI, FUNDAMENTAL, DAN RESIKO SISTEMIS (BETA SAHAM) TERHADAP RETURN SAHAM SYARIAH YANG TERDAFTAR DI JAKARTA ISLAMIC INDEX (JII)
}

\author{
Purboyo $^{1}$, Rizka Zulfikar ${ }^{2}$ \\ Email: ${ }^{1}$ mail.purboyo@ gmail.com, ${ }^{2}$ rizkazulfikar@gmail.com
}

Fakultas Ekonomi Universitas Islam Kalimantan MAB Banjarmasin

\begin{abstract}
This study aims to determine the effect of macroeconomic factors, corporate fundamentals and systemic risk on the return of Islamic stocks listed on the Indonesian stock exchanges incorporated in Jakarta Islamic Index (JII) stocks during the period 2013 to 2016, the sampling of data using purposive sampling method, there are 11 syariah-compliant companies which for four years or eight consecutive times entered into JII index during the observation period between 2013 and 2016 sampled, while the variables studied consist of GDP (Gross Domestic Product), inflation, DER (Debt to Equity Ratio), ROA (Return On Assets), BETA (systemic risk) and stock return. The test method using multiple regression analysis with SPSS test, the result of statistical test with $\mathrm{F}$ test (F-test) got the result that all independent variables (GDP, inflation, DER, ROA, BETA) simultaneously have significant effect to stock return with significance level 0,002 , the result of statistical test with $t$ test (t-test) there are two variables that is inflation with significance level 0,017 and DER with significance level 0,030 have significant effect to return of syariah stock, while other variable that is GDP, ROA and BETA have no significant effect to stock return sharia.
\end{abstract}

Keywords: Sharia stock, GDP, Inflation, Corporate fundamentals, systemic risk, Stock return

\section{PENDAHULUAN}

Pasar modal syariah di Indonesia saat ini telah tumbuh dan berkembang selama kurun waktu dua dekade atau selama 20 tahun, yaitu ditandai semenjak diluncurkanya produk reksa dana syariah di tahun 1997. Produk pasar modal syariah di Indonesia saat ini juga cukup beragam yaitu terdiri dari saham syariah, sukuk dan reksa dana syariah.

Meskipun Indonesia mempunyai jumlah penduduk Islam terbesar di dunia tidak serta merta industri pasar modal syariah mendominasi market share pasar modal secara keseluruhan, berdasarkan data OJK dalam road map pasar modal syariah 2015-2019 bahwa market share 
untuk sukuk dan reksadana syariah kurang dari 5\%, sedangkan untuk saham syariah yang telah tercatat di Bursa Efek Indonesia (BEI) berada dikisaran 50\% (Data Direktorat Pasar Modal Syariah Otoritas Jasa Keuangan, 2016). Pada dasarnya investor yang masuk ke pasar saham syariah mempunyai tujuan yang sama dengan investor di pasar saham konvensional yaitu sama-sama ingin mendapatkan return saham, resiko dipasar saham syariah juga hampir sama dengan dipasar konvensional berupa resiko capital loss, resiko tidak ada pembagian deviden, resiko likuidasi dan delisting dari bursa.

Penelitian sebelumnya (Supadi \& Amin, 2014) meneliti pengaruh faktor fundamental dan risiko sistemis terhadap return saham syariah menemukan bahwa variabel Earning Per Share (EPS), Return On Equity (ROE), Debt to Equity Ratio (DER), beta saham tidak berpengaruh signifikan terhadap return saham, namun hasil yang berbeda didapatkan oleh penelitian (Azwar., et al, 2010) yang menemukan bahwa Debt to Equity Ratio (DER), Return on Equity (ROE) berpengaruh signifikan terhadap return saham. Hasil yang berbeda didapatkan dalam penelitian (Darminto \& Saifi, 2014) yang menemukan bahwa variabel Return On Asset (ROA), Debt to Equity Ratio (DER), Price to Book Value (PBV), kurs, inflasi dan suku bunga secara simultan signifikan pengaruhnya terhadap return saham, Secara parsial terdapat pengaruh signifikan variabel Return On Asset (ROA), Debt to Equity Ratio (DER), dan Price to Book Value (PBV) terhadap variabel return saham. Selanjutnya penelitian (Sinaga \& Triaryati, 2014) menemukan variabel Return On Equity (ROE), Price to Book Value (PBV) secara parsial berpengaruh positif signifikan terhadap return saham, sedangkan Debt to equity ratio (DER), inflasi dan Produk Domestik Bruto (PDB) tidak berpengaruh signifikan.

Penelitian ini bertujuan untuk meneliti faktor-faktor yang mempengaruhi return saham, dan topik yang akan diteliti adalah pengaruh faktor makroekonomi, fundamental, dan resiko sistemis (beta saham) terhadap return saham syariah yang terdaftar di Jakarta Islamic Index (JII).

Adapun kerangka pikir yang dibuat adalah sebagai berikut: 


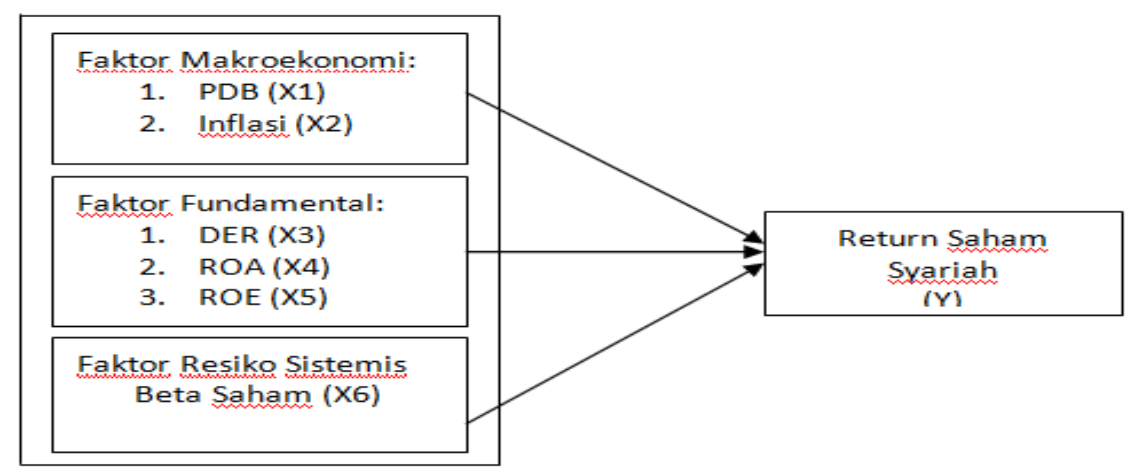

Gambar 1. Kerangka Pikir Penelitian

Adapun Hipotesis dalam penelitian ini:

1. H1: Faktor makroekonomi yang diproksikan dengan Produk Domestik Bruto (PDB) berpengaruh positif dan signifikan terhadap return saham syariah.

2. H2: Faktor makroekonomi yang diproksikan dengan Inflasi berpengaruh positif dan signifikan terhadap return saham syariah.

3. H3: Faktor Fundamental yang diproksikan dengan Debt to Equity Ratio (DER) berpengaruh negatif dan signifikan terhadap return saham syariah.

4. H4: Faktor Fundamental yang diproksikan dengan Return On Asset (ROA) berpengaruh positif dan signifikan terhadap return saham syariah.
5. H5: Faktor Fundamental yang diproksikan dengan Return On Equity (ROE) berpengaruh positif dan signifikan terhadap return saham syariah.

6. H6: Resiko sistemis yang diproksikan dengan Beta Saham berpengaruh positif dan signifikan terhadap return saham syariah.

\section{METODE PENELITIAN}

Jenis penelitian ini merupakan penelitian kausalitas yakni penelitian yang ingin mencari penjelasan dalam bentuk pengaruh hubungan atau sebab akibat antara beberapa variabel independen yaitu Pendapatan Domestik Bruto (PDB), Inflasi, Debt to Equity Ratio (DER), Return On Asset (ROA), Return On Equity (ROE), resiko sistemis (beta Saham) dengan variabel dependen yaitu return saham. 
Populasi dalam penelitian ini adalah seluruh perusahaan yang terdaftar dalam Bursa Efek Indonesia (BEI) dan yang tergabung dalam kelompok saham Jakarta Islamic Index (JII) selama periode pengamatan yaitu tahun 2013 sampai tahun 2016, didalam website Bursa Efek Indonesia (BEI) dijelaskan kelompok saham JII adalah berisi 30 saham yang merupakan saham-saham syariah yang paling likuid dan memiliki kapitalisasi pasar yang besar.

Tabel 1.

Daftar saham yang masuk dalam Jakarta Islamic Index (JII) dan dijadikan sampel penelitian

\begin{tabular}{|c|l|l|}
\hline No & Kode & Nama Saham \\
\hline 1 & AALI & Astra Agro Lestari Tbk \\
\hline 2 & ADRO & Adaro Energy Tbk \\
\hline 3 & AKRA & AKR Corporindo Tbk \\
\hline 4 & ASII & Astra International Tbk \\
\hline 5 & INTP & Indocement Tunggal Prakarsa Tbk \\
\hline 6 & LPKR & Lippo Karawaci Tbk \\
\hline 7 & LSIP & PP London Sumatra Indonesia Tbk \\
\hline 8 & SMGR & Semen Indonesia Tbk \\
\hline 9 & TLKM & Telekomunikasi Indonesia (Persero) Tbk \\
\hline 10 & UNTR & United Tractors Tbk \\
\hline 11 & UNVR & Unilever IndonesiaTbk \\
\hline
\end{tabular}

Sumber: Bursa Efek Indonesia (data diolah)

Jenis data yang digunakan dalam penelitian ini merupakan data sekunder berupa laporan keuangan perusahaan, data transaksi saham syariah dari Bursa Efek Indonesia (BEI), data Pendapatan Domestik Bruto (PDB), data inflasi, kemudian data diolah untuk tujuan penelitian ini. Sumber-sumber data penelitian ini diperoleh dari berbagai sumber diantaranya Bursa Efek
Indonesia (BEI), Yahoo Finance, Google Finance, Indonesia Capital Market Directory (ICMD), Badan Pusat Statistik (BPS), Otoritas Jasa Keuangan (OJK), Bank Indonesia (BI).

$$
\text { Penjelasan variabel-variabel yang }
$$
yang digunakan adalah sebagai berikut:

1. Produk Domestik Bruto (PDB) PDB adalah seluruh nilai barangbarang dan jasa-jasa yang 
diproduksikan didalam suatu negara dalam satu tahun tertentu (Sukirno Sadono, 2015:34). PDB dapat mencerminkan tingkat kesejahteraan masyarakat, semakin tinggi PDB maka semakin tinggi tingkat pendapatan masyarakat sehingga tingkat penjualan produk juga akan meningkat yang pada akhirnya meningkatkan laba perusahaan (Sinaga \& Triaryati, 2014). Adapun rumusan untuk mendapatan PDB adalah (Sukirno Sadono, 2015:35)

$$
\mathrm{PDB}=
$$

PNB - PFN dari LN

2. Inflasi

Inflasi adalah meningkatnya harga produk-produk secara keseluruhan yang dapat menyebabkan penurunan daya beli masyarakat (Tandelilin, 2010:342). Tingkat inflasi yang tinggi umumnya dikaitkan dengan kondisi ekonomi yang overheated, yaitu kondisi ekonomi mengalami permintaan melebihi kapasitas produknya sehingga harga-harga mengalami kenaikan (Darminto \& Saifi, 2014). Di dalam penjelasan Bank Indonesia dikatakan bahwa indikator inflasi dapat diukur dengan pendekatan Indeks Harga
Perdagangan Besar (IHPB) dan Deflator Produk Domestik Bruto (PDB) atas dasar harga konstan .

3. Debt to Equity Ratio (DER) DER dapat diartikan sebagai ratio utang terhadap ekuitas, ratio ini menggambar kan besarnya jumlah hutang yang dimiliki perusahaan dengan membandingkan antara jumlah hutang dengan jumlah ekuitas (Gallagher \& Andrew Jr, 1999:91). Semakin rendah ratio DER maka kemampuan perusahaan dalam memenuhi kewajiban hutangnya akan semakin baik, DER dapat diketahui dengan rumusan (Supadi \& M. Nuryanto Amin, 2014).

$$
\begin{array}{ll}
\text { DER } & \text { Total Debt } \\
\hline & \text { Total Equity }
\end{array}
$$

4. Return On Asset (ROA)

ROA adalah perbandingan antara laba bersih setelah pajak dengan jumlah aktiva, semakin besar ROA menunjukkan kinerja perusahaan semakin baik, karena tingkat kembalian saham semakin besar atau semakin meningkatnya harga ataupun return saham (Nugraha, 2014). ROA dapat diketahui dengan rumusan 


$$
\text { ROA }=\frac{\text { Net Income After Tax }}{\text { Total Asset }}
$$

5. Return On Equity (ROE)

ROE adalah rasio yang digunakan untuk mengukur tingkat efektifitas dalam memperoleh keuntungan dari investasi yang telah dilakukan oleh pemegang saham (Husnan , 2005:331), ROE diperoleh dengan rumusan

$\mathrm{ROE}=\frac{\text { Net Income After Tax }}{\text { Equity }}$

Semakin tinggi ROE berarti semakin baik kinerja suatu perusahaan dalam mengelola modal untuk menghasilkan laba, dengan meningkatnya laba diharapkan para investor tertarik untuk membeli saham tersebut yang akhirnya harga saham perusahaan tersebut akan meningkat (Nugraha, 2014).$$
\mathrm{Ri}=\alpha 0+\alpha 1 \mathrm{Rm}
$$$$
\text { Ri : Tingkat keuntungan saham ke i }
$$$$
\alpha 0 \quad \text { : Bagian dari tingkat keuntungan saham i yang tdk dipengaruhi oleh perubahan pasar }
$$$$
\alpha 1 \quad \text { : Beta saham, parameter yang mengukur perubahan yang diharapkan pada Ri jika terjadi perubahan Rm }
$$$$
\mathrm{Rm} \quad \text { : Tingkat keuntungan indeks pasar }
$$

7. Return Saham

Return saham adalah tingkat keuntungan yang diperoleh oleh pemegang saham atau pemodal atas investasi yang dilakukannya, return saham dapat dihitung dengan rumusan (Jogiyanto, 2010:207). 


$$
\begin{array}{ll}
\mathrm{Ri}= & \frac{\mathrm{Pt}-\mathrm{Pt}-1+\mathrm{Dt}}{\mathrm{Pt}-1} \\
\mathrm{Ri} \quad \text { : return saham i pada periode } \mathrm{t} \\
\mathrm{Pt}: \quad \text { : harga penutupan saham i pada periode } \mathrm{t} \text { (periode terakhir) } \\
\mathrm{Pt}-1 \quad \text { : harga penutupan saham i pada periode sebelumnya (awal) } \\
\text { Dt } \quad \text { : Yield pada periode } \mathrm{t}
\end{array}
$$

Metode Analisis dilakukan menggunakan program SPSS for Windows versi 18.0, dengan model yang dianalisa adalah model regresi berganda yang dinyatakan dalam persamaan berikut:

$\mathrm{Y}=$

$a+b 1 X 1+b 2 X 2+b 3 X 3+b 4 X 4+b 5 X 5+b 6$

$\mathrm{X} 6+\mathrm{e}$

Dimana:

$\mathrm{Y}=$ Variabel dependen return saham syariah

$$
\alpha=\text { Nilai Konstanta }
$$

\section{HASIL DAN PEMBAHASAN}

\section{Analisis Deskriptif Data}

$\mathrm{b} 1, \mathrm{~b} 2, \mathrm{~b} 3, \mathrm{~b} 4, \mathrm{~b} 5, \mathrm{~b} 6=$ Koefisien korelasi X1,X2,X3,X4,X5,X6

$\mathrm{X} 1=$ Variabel independen PDB

$\mathrm{X} 2=$ Variabel independen Inflasi

X3 = Variabel independen DER

$\mathrm{X} 4=$ Variabel independen ROA

$\mathrm{X} 5=$ Variabel independen $\mathrm{ROE}$ saham

X6 = Variabel independen Beta error)

$\mathrm{e}=$ Besaran nilai residu (standar

Tabel 2. Deskriptif Data

\begin{tabular}{|l|r|r|r|r|r|}
\hline & & $\begin{array}{c}\text { Minimu } \\
\mathrm{m}\end{array}$ & $\begin{array}{c}\text { Maximu } \\
\mathrm{m}\end{array}$ & \multicolumn{1}{c|}{ Mean } & \multicolumn{1}{c|}{ Dtd. } \\
& $\mathrm{N}$ & \multicolumn{1}{c|}{ Deviation } \\
\hline X1_PDB & 44 & 9546.00 & 12407.00 & 11038.7500 & 1070.49771 \\
X2_INFLASI & 44 & 3.53 & 6.97 & 5.8250 & 1.36093 \\
X3_DER & 44 & .13 & 2.56 & .8345 & .59401 \\
X4_ROA & 44 & 2.48 & 71.51 & 12.7255 & 12.61827 \\
X5_ROE & 44 & 4.50 & 135.85 & 24.8225 & 33.27936 \\
X6_BETA & 44 & .13 & 2.20 & .9102 & .64086
\end{tabular}




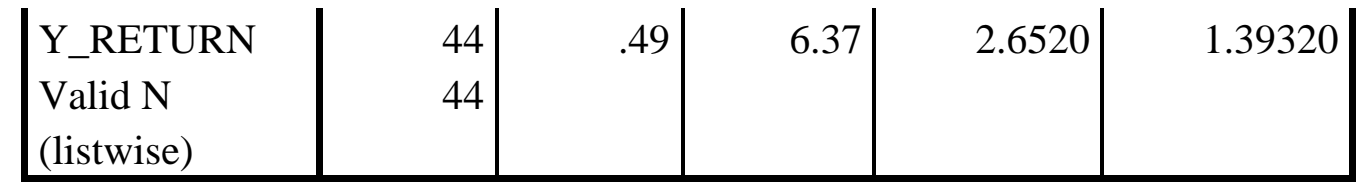

Sumber: data sekunder yang diolah, 2016

Penelitian ini menggunakan data dalam bentuk pooled cross sectional, dimana periode data penelitian dilakukan pada tahun 2013 - 2016, dengan sampel sebanyak 11 perusahaan, maka pooled cross sectional diperoleh sejumlah $11 \mathrm{x}$ 4 = 44 data. Dari tabel 2 dapat dijelaskan bahwa rata-rata PDB Indonesia dari tahun 2013 - 2016 sebesar Rp.11.038,75 trilliun, dari data BPS dilaporkan bahwa dari tahun 2013 sampai dengan tahun 2016 PDB mengalami peningkatan dimana tahun 2013 PDB sebesar Rp.9.546 trilliun dan di tahun 2016 meningkat menjadi Rp.12.406,8 trilliun (BPS, 2017). Peningkatan PDB dapat mencerminkan tingkat kesejahteraan masyarakat, semakin tinggi PDB maka semakin tinggi tingkat pendapatan masyarakat, dan memberikan kesempatan lebih banyak kepada masyarakat untuk dapat berinvestasi dipasar modal.

Rata-rata inflasi sebesar $5.82 \%$, inflasi tertinggi ditahun 2013 dengan tingkat inflasi sebesar $6.97 \%$ dan inflasi terendah ditahun 2016 sebesar $3.53 \%$, tingkat inflasi di Indonesia sepanjang tahun 2013 sampai tahun 2016 masih dalam taraf wajar dan terkendali dimana inflasi tidak pernah melebihi angka 7\%, hal ini memberikan dampak yang cukup baik bagi iklim usaha dan investasi dipasar modal.

Rata-rata DER untuk perusahaan yang terdaftar di Jakarta Islamic Index sebesar 0.83 kali, hal ini menunjukkan bahwa perusahaan-perusahaan yang sahamnya terdaftar di JII adalah perusahaan yang cukup baik dalam mengelola dan menjaga ratio hutang, dimana tidak ada perusahaan yang DER nya melampaui ketentuan pemerintah, yaitu batasan DER yang diperbolehkan adalah maksimal sebesar 4 kali dari modal sendiri atau 4:1 (PMK no.169/PMK.010/2015, 2015).

ROA rata-rata untuk perusahaan yang tergabung dalam indeks saham JII sebesar $12,72 \%$, hal ini menunjukkan perusahaan yang tergabung dalam saham JII memiliki kemampuan menghasilkan laba dari total aktiva dengan cukup baik selama periode penelitian. ROE rata-rata 
sebesar 24,82\% juga menggambarkan kemampuan perusahaan menghasilkan pengembalian modal sendiri yang cukup baik selama periode penelitian.

Beta saham rata-rata sebesar $0.91 \%$, hal ini menandakan bahwa ratarata resiko pada saham syariah relatif rendah karena beta saham $<1$, Beta saham tertinggi selama periode penelitian yaitu sebesar 2.20 dimiliki oleh kode saham ADRO dengan nama perusahaan PT. Adaro Energy Tbk dan Beta saham terendah sebesar 0.13 dimiliki oleh kode saham UNTR denga nama perusahaan PT. United Tractors Tbk.
Rata-rata return saham syariah sebesar 2,65, return saham bisa positif bisa juga negatif, jika return saham negatif berarti mendapatkan kerugian atau capital lost dan jika return saham positif berarti mendapatkan keuntungan atau capital gain, semakin tinggi return saham tentunya akan semakin diharapkan karena dapat memberikan keuntungan yang maksimal. Return saham tertinggi sebesar 6.37 ada pada kode saham ADRO (PT. Adaro Energy Tbk ) ditahun 2015 dan return saham terendah sebesar 0,49 ada pada kode saham LPKR (PT. Lippo Karawaci Tbk).

\section{Pengujian Hipotesis}

Tabel 6. Hasil analisis Koefisien Regresi

Coefficients $^{\mathbf{a}}$

\begin{tabular}{|c|c|c|c|c|c|}
\hline \multirow[t]{2}{*}{ Model } & \multicolumn{2}{|c|}{$\begin{array}{c}\text { Unstandardized } \\
\text { Coefficients }\end{array}$} & \multirow{2}{*}{$\begin{array}{c}\begin{array}{c}\text { Standardize } \\
\mathrm{d} \\
\text { Coefficients }\end{array} \\
\text { Beta } \\
\end{array}$} & \multirow[b]{2}{*}{$\mathrm{t}$} & \multirow[b]{2}{*}{ Sig. } \\
\hline & B & Std. Error & & & \\
\hline (Constant) & -.991 & 4.723 & & -.210 & .835 \\
\hline X1_PDB & $6.179 \mathrm{E}-5$ & .000 & .047 & .199 & .843 \\
\hline $\begin{array}{l}\text { X2_INFLA } \\
\text { SI }\end{array}$ & .604 & .242 & .590 & 2.498 & .017 \\
\hline X3_DER & -.803 & .357 & -.343 & -2.253 & .030 \\
\hline X4_ROA & .006 & .018 & .052 & .327 & .746 \\
\hline X6_BETA & .045 & .292 & .021 & .153 & .879 \\
\hline $\begin{array}{c}R \\
R \text { squa } \\
\text { Adj. R sq }\end{array}$ & $\begin{array}{l}=0.624 \\
=0.389 \\
=0.309\end{array}$ & & & & \\
\hline
\end{tabular}


Dari hasil perhitungan analisis koefisien regresi maka persamaan regresi linear berganda dengan tingkat signifikansi sebesar 5\% dapat dirumuskan persamaan sebagai berikut: $\mathrm{Y}=-0.991+0.00006179 \mathrm{X} 1+0.604 \mathrm{X} 2$ $-0.803 \times 3+0.006 \times 4+0.045 \times 6$ Berdasarkan tabel 6 dan persamaan regresi linear diatas terdapat beberapa variabel yang signifikan dengan nilai Sig $<0.05$ yaitu variabel (X2) Inflasi dan variabel (X3) Debt to Equity Ratio (DER), sedangkan variabel (X1) Produk
Domestik Bruto (PDB), variabel (X4) Return On Asset (ROA), variabel (X6) BETA Saham tidak signifikan karena nilai Sig > 0.05. Nilai Adjusted $\mathrm{R}$ Square sebesar 0.309 yang berarti bahwa pengaruh faktor makroekonomi (PDB, Inflasi) faktor fundamental (DER,ROA) dan saham BETA terhadap return saham syariah sebesar $30.90 \%$ dan sisanya sebesar $69.10 \%$ dipengaruhi oleh variabel lain.

\section{Uji F (F-test )}

Tabel 7. Hasil Uji F (F-test)

\begin{tabular}{|ll|r|r|r|r|r|}
\hline Model & \multicolumn{1}{c|}{$\begin{array}{c}\text { Sum of } \\
\text { Squares }\end{array}$} & df & Mean Square & F & Sig. \\
\hline 1 & Regression & 32.509 & 5 & 6.502 & 4.849 & $.002^{a}$ \\
& Residual & 50.955 & 38 & 1.341 & & \\
& Total & 83.464 & 43 & & & \\
& & & & & \\
\hline
\end{tabular}

a. Predictors: (Constant), X6_BETA, X2_INFLASI, X3_DER, X4_ROA, X1_PDB

b. Dependent Variable: Y_RETURN

Uji F dilakukan untuk mengetahui kelayakan model regresi dan pengaruh simultan variabel-variabel independen terhadap variabel dependen, jika nilai $\mathrm{F}$ hitung > nilai $\mathrm{F}$ tabel dan nilai Sig. F hitung $<0.05$ maka variabel PDB, Inflasi, DER, ROA, BETA secara simultan mempunyai pengaruh signifikan terhadap return saham dan kelayakan model terpenuhi. Dari hasil output regresi spss Uji F didapatkan nilai F hitung sebesar 4.849 lebih besar dari pada F tabel sebesar 2.46, dan nilai Sig. F=0.002 < 0.05 maka model regresi memenuhi kelayakan. 


\section{Uji Korelasi}

Tabel 8. Hasil Uji Korelasi

\begin{tabular}{|c|c|c|c|c|}
\hline $\begin{array}{l}\text { Independe } \\
\text { nt }\end{array}$ & $\begin{array}{l}\leftrightarrow \\
\text { Dependent }\end{array}$ & $\begin{array}{c}\text { Person } \\
\text { Correlati } \\
\text { on }\end{array}$ & Sig (2 Tailed) & Kesimpulan \\
\hline X1_PDB & $\stackrel{\leftrightarrow}{\text { Y_RETURN }}$ & $-0.439^{* *}$ & 0.003 & $\begin{array}{l}\text { H0 ditolak, korelasi } \\
\text { sedang - negatif }\end{array}$ \\
\hline $\begin{array}{l}\text { X2_INFLA } \\
\text { SI }\end{array}$ & $\stackrel{\leftrightarrow}{\text { Y_RETURN }}$ & $0.537^{* *}$ & 0.000 & $\begin{array}{l}\text { H0 ditolak, korelasi } \\
\text { sedang - positif }\end{array}$ \\
\hline X3_DER & $\stackrel{\leftrightarrow}{\text { Y_RETURN }}$ & -0.286 & 0.060 & $\begin{array}{l}\text { H0 diterima, tidak ada } \\
\text { korelasi }\end{array}$ \\
\hline X4_ROA & $\begin{array}{l}\leftrightarrow \\
\text { Y_RETURN }\end{array}$ & -0.078 & 0.615 & $\begin{array}{l}\text { H0 diterima, tidak ada } \\
\text { korelasi }\end{array}$ \\
\hline X5_ROE & $\begin{array}{l}\leftrightarrow \\
\text { Y_RETURN }\end{array}$ & -0.196 & 0.203 & $\begin{array}{l}\text { H0 diterima, tidak ada } \\
\text { korelasi }\end{array}$ \\
\hline X6_BETA & $\overleftrightarrow{\text { Y_RETURN }}$ & -0.013 & 0.931 & $\begin{array}{l}\text { H0 diterima, tidak ada } \\
\text { korelasi }\end{array}$ \\
\hline
\end{tabular}

Secara umum uji korelasi adalah untuk mempelajari apakah ada hubungan antara dua variabel atau lebih, sedang analisis regresi adalah untuk memprediksi seberapa jauh pengaruh tersebut (Santoso, 2012:197). Sehingga jika analisis korelasi menyatakan adanya hubungan yang kuat-tidaknya antara variabel-variabel tersebut, maka analisis regresi akan memprediksi seandainya salah satu variabel independen ditingkatkan / diturunkan sekian kali maka berapa kali peningkatan / penurunan variabel dependen akan dicapai. Dari tabel 8 uji korelasi dapat dijelaskan sebagai berikut:

1. Variabel PDB berkorelasi negatif dengan kekuatan sedang (0.439) dan signifikan dengan variabel return saham syariah karena nilai Signifikansi pada level $5 \%<0.05$, meskipun berdasarkan hasil regresi variabel PDB tidak memiliki pengaruh yang signifikan terhadap return saham, namun ada kecenderungan bahwa pengaruh yang diberikan variabel PDB masih 
memiliki nilai korelasi dengan nilai return saham syariah.

2. Variabel Inflasi berkorelasi positif dengan kekuatan sedang dan signfikan dengan variabel return saham syariah karena memiliki nillai signfikansi $<0.05$ Jadi dapat dikatakan bahwa pengaruh signfikan diberikan oleh variabel Inflasi terhadap variabel retun saham syariah juga disebabkan adanya korelasi antara variabel Inflasi dengan Return saham syariah.

3. Variabel-variabel lain sepeti DER, ROA, ROE dan BETA tidak memiliki korelasi yang signifikan terhaadap variael return saham syariah. Hal ini juga ditunjukkan tidak signifikannya pengaruh variabel-variabel ini terhadap return saham pada analisis regresi.

\section{Uji t (t-test)}

Tabel 9. Hasil Uji t (t-test)

\begin{tabular}{|c|c|c|c|c|c|c|c|}
\hline \multirow{2}{*}{\multicolumn{2}{|c|}{ Model }} & \multicolumn{2}{|c|}{$\begin{array}{c}\text { Unstandardized } \\
\text { Coefficients }\end{array}$} & \multirow{2}{*}{$\begin{array}{c}\text { Standardized } \\
\text { Coefficients } \\
\text { Beta }\end{array}$} & \multirow[b]{2}{*}{$t$} & \multirow[b]{2}{*}{ Sig. } & \multirow{2}{*}{$\begin{array}{c}\text { Keterangan } \\
\text { Hasil }\end{array}$} \\
\hline & & $\mathrm{B}$ & Std. Error & & & & \\
\hline \multirow[t]{6}{*}{1} & (Constant) & -.991 & 4.723 & & -.210 & .835 & \\
\hline & X1_PDB & $6.179 E-5$ & .000 & .047 & .199 & .843 & Tidak Signifikan \\
\hline & X2_INFLASI & .604 & .242 & .590 & 2.498 & .017 & Signifikan \\
\hline & X3_DER & -.803 & .357 & -.343 & -2.253 & .030 & Signifikan \\
\hline & X4_ROA & .006 & .018 & .052 & .327 & .746 & Tidak Signifikan \\
\hline & X6_BETA & .045 & .292 & .021 & .153 & .879 & Tidak Signifikan \\
\hline
\end{tabular}

Uji $t$ atau pengujian secara parsial digunakan untuk menguji secara parsial variabel independen yang terdiri dari Produk Domestik Bruto (PDB), Inflasi, Debt to Equity Ratio (DER), Return On Assets (ROA), dan Beta saham terhadap variabel dependen (return saham syariah), uji $\mathrm{t}$ juga dilakukan untuk menguji hipotesis apakah hipotesis diterima atau ditolak . Jika nilai Sig. < 0.05 maka secara parsial variabel independen berpengaruh signifikan terhadap variabel dependen (return saham syariah) maka hipotesis diterima, jika nilai Sig. > 0.05 maka secara parsial variabel independen tidak 
berpengaruh signifikan terhadap variabel dependen (return saham syariah) maka hipotesis ditolak (tidak diterima). Dari output regresi SPSS didapatkan hasil berikut:

- Faktor makroekonomi yang diproksikan dengan Pendapatan Domestik Bruto (PDB) dengan nilai Sig.0.843>0.05, dapat disimpulkan bahwa variabel Pendapatan Domestik Bruto (PDB) secara parsial berpengaruh positif tetapi tidak signifikan terhadap return saham syariah, sehingga hipotesis 1 yang menduga Produk Domestik Bruto (PDB) berpengaruh positif dan signifikan terhadap return saham syariah tidak dapat diterima. Hasil ini sejalan dengan hasil penelitian yang dilakukan oleh (Sinaga \& Triaryati, 2014) yang menemukan bahwa variabel PDB tidak berpengaruh terhadap harga saham, dan juga penelitian (Kewal, 2012) yang juga menemukan variabel PDB tidak berpengaruh signifikan terhadap return saham.

- Faktor makroekonomi yang diproksikan dengan Inflasi dengan nilai Sig.0.017 < 0.05 , dapat disimpulkan bahwa variabel Inflasi secara parsial berpengaruh positif dan signifikan terhadap return saham syariah, sehingga hipotesis 2 yang menduga inflasi berpengaruh positif dan signifikan terhadap return saham syariah dapat diterima. Hasil ini sejalan dengan hasil peneltian yang dilakukan oleh (Suyati, 2015) yang menemukan bahwa secara parsial variabel inflasi berpengaruh signifikan terhadap return saham, namun berbeda dengan hasil penelitian (Setyowati \& Ningsih, 2016) yang menemukan bahwa inflasi tidak berpengaruh signifikan terhadap return saham.

- Faktor fundamental yang diproksikan dengan Debt to Equity Ratio (DER) dengan nilai Sig.0.030 $<0.05$, dapat disimpulkan bahwa variabel DER secara parsial berpengaruh negatif signifikan terhadap return saham syariah, sehingga hipotesis 3 yang menduga Debt to Equity Ratio (DER) berpengaruh negatif dan signifikan terhadap return saham syariah dapat diterima. Hasil ini sejalan dengan hasil peneltian yang dilakukan oleh (Ismayanti \& Yuniar, 2014), (Putri \& Sampurno, 2012) dan penelitian 
(Azwar et al., 2010) yang menemukan bahwa variabel DER berpengaruh signifikan terhadap return saham, berbeda dengan penelitian (Supadi \& Amin, 2014) yang menemukan hasil bahwa DER tidak berpengaruh signifikan terhadap return saham.

- Faktor fundamental yang diproksikan dengan Return On Asset (ROA) dengan nilai Sig.0.0746 > 0.05, dapat disimpulkan bahwa variabel ROA secara parsial berpengaruh positif tetapi tidak signifikan terhadap return saham syariah, sehingga hipotesis 4 yang menduga Return On Asset (ROA) berpengaruh positif dan signifikan terhadap return saham syariah tidak dapat diterima. Hasil ini sejalan dengan hasil penelitian yang dilakukan oleh (Yeye \& Tri, 2011) dan (Putri \& Sampurno, 2012) yang menemukan bahwa variabel ROA tidak berpengaruh signifikan terhadap return saham.

- Resiko sistemis yang diproksikan dengan Beta saham dengan nilai Sig.0.0879 > 0.05, dapat disimpulkan bahwa variabel Beta saham secara parsial berpengaruh positif tetapi tidak signifikan terhadap return saham syariah, sehingga hipotesis 6 yang menduga Beta Saham berpengaruh positif dan signifikan terhadap return saham syariah tidak dapat diterima. Hasil ini sejalan dengan hasil peneltian yang dilakukan oleh (Supadi \& Amin, 2014), (Setyowati \& Ningsih, 2016) yang menemukan bahwa variabel Beta saham tidak berpengaruh signifikan terhadap return saham.

\section{KESIMPULAN DAN SARAN}

\section{Kesimpulan}

1. Secara simultan Faktor makroekonomi, fundamental dan resiko sistemis berpengaruh signifikan terhadap return saham syariah yang tergabung dalam saham Jakarta Islamic Index (JII).

2. Secara parsial variabel Inflasi dan variabel Debt to Equity Ratio (DER) berpengaruh signifikan terhadap return saham syariah yang tergabung dalam saham Jakarta Islamic Index (JII).

3. Secara parsial variabel Produk Domestik Bruto (PDB), Return On Asset (ROA) dan Beta saham tidak 
berpengaruh signifikan terhadap return saham syariah yang tergabung dalam saham Jakarta Islamic Index (JII).

4. Variabel Return On Equity (ROE) tidak dijelaskan lebih lanjut dalam penelitian ini karena saat uji asumsi klasik mengandung gejala multikolinearitas sehingga variabel Return On Equity (ROE) dikeluarkan dari model regresi dalam penelitian ini.

5. Penelitian ini mempunyai beberapa keterbatasan yaitu hasil regresi linier berganda dengan melihat nilai $\mathrm{Adj}$. $R$ square bahwa pengaruh faktor makroekonomi (PDB, Inflasi) faktor fundamental (DER,ROA) dan Resiko (Beta) terhadap return saham syariah hanya sebesar $30.90 \%$ sedangkan sisanya sebesar $69.10 \%$ dipengaruhi oleh variabel lain yang tidak diteliti dalam penelitian ini.

\section{Saran}

1. Investor diharapkan sebelum memutuskan untuk berinvestasi di pasar modal syariah perlu terlebih dahulu melakukan analisa terhadap laporan keuangan yaitu struktur fundamental, makroekonomi dan resiko sistemis karena hasil penelitian ini menunjukkan secara simultan faktor-faktor tersebut berpengaruh signifikan terhadap return saham syariah.

2. Dikarenakan adanya resiko investasi maka sebelum memutuskan untuk berinvestasi di pasar modal syariah sepatutnya investor juga melihat faktor-faktor lain yang dapat mempengaruhi pergerakan harga saham yang tidak diteliti dalam penelitian ini yaitu faktor politik, psikologis pasar dan harga komoditas seperti harga emas, harga minyak dunia.

3. Penelitian selanjutnya diharapkan dapat meneliti variabel lain yang dapat mempengaruhi return saham yang tidak diteliti dalam penelitian ini seperti variabel kurs (nilai tukar), bunga Bank, Price Earning Ratio (PER), situasi politik, psikologis pasar dan harga komoditas yang dapat mempengaruhi harga saham.

4. Objek penelitian ini terbatas pada saham-saham syariah yang tergabung dalam Jakarta Islamic Index (JII) dengan periode tahun 2013 - 2016 . Penelitian selanjutnya dapat meneliti seluruh saham syariah yang terdaftar 
di Bursa Efek Indonesia (BEI) atau memperpanjang periode penelitian.

\section{DAFTAR PUSTAKA}

Azwar, Yama, I., Mufrani, A., Suhendra, \& Noor, S. (2010). Analisis Faktor Fundamental Terhadap Excess Return Saham Syariah Perusahaan Jakarta Islamic Index. Al-Iqtishad, 3 (1)(Januari 2011), 127-140.

BPS (Badan Pusat Statistik). (2017). Produk Domestik Bruto Indonesia 2012-2016. Https://www.bps.go.id, $1-105$.

Darminto, A. P., \& Saifi, M. (2014). Faktor Internal dan Eksternal yang Mempengaruhi Pergerakan Harga Saham (Studi Pada Saham-Saham Indeks LQ45 Periode 2009 - 2013). Jurnal Administrasi Bisnis, 11 (1)(Juni 2014), 1-9.

Direktorat Pasar Modal Syariah Otoritas Jasa Keuangan. (2016). Roadmap Pasar Modal Syariah 2015 - 2019. Http://www.ojk.go.id, 1-103.

Ferdinand Augusty. (2006). Metode Penelitian Manajemen: Pedoman Penelitian untuk Penulisan Skripsi, Tesis dan Disertasi Ilmu Manajemen (2nd ed.). Semarang: Badan Penerbit Universitas Diponegoro, CV.Indoprint Semarang.

Gallagher, T. J., \& Joseph D. Andrew Jr. (1999). Financial Management: Principles and Practise. New Jersey: Prentice Hall Inc.

Husnan Suad. (2005). Dasar-Dasar Teori Portofolio dan Analisis
Sekuritas. Yogyakarta: AMP
YPKN.

Ismayanti, D., \& Yuniar, M. W. (2014). Pengaruh Faktor Fundamental dan Risiko (Beta) Terhadap Return Saham pada Perusahaan yang Termasuk Dalam Indeks LQ 45. Jurnal Wawasan Manajemen, 2 (1)(Februari 2014), 1-20.

Jogiyanto Hartono. (2010). Teori Portofolio dan Analisis Investasi (7th ed.). Yogyakarya: BPFE Fakultas Ekonomi Universitas Gadjah Mada.

Kewal, S. S. (2012). Pengaruh Inflasi, Suku Bunga, Kurs, dan Pertumbuhan PDB Terhadap Indeks Harga Saham Gabungan. Jurnal Economia, 8 (1)(April 2012), 5364.

Kurniawan, R. D., \& Asandimitra, N. (2014). Analisis Perbandingan Kinerja Indeks Saham Syariah dan Kinerja Indeks Saham Konvensional. Jurnal Ilmu Manajemen, 2 (4)(Oktober 2014), 1356-1366.

Menteri Keuangan. PMK169/PMK.010/2015 Penentuan Besarnya Perbandingan antara utang dan modal perusahaan (2015).

Nugraha, F. A. (2014). Pengaruh Analisis Fundamental Terhadap Return Saham Perusahaan (Studi Empiris pada Perusahaan Manufaktur yang Terdaftar di Bursa Efek Indonesia Periode 2010-2014.

Otoritas Jasa Keuangan. Penerapan Prinsip Syariah di Pasar Modal, 
Pub. L. No. 15/POJK.04/2015, OJK 1 (2015). Indonesia. Retrieved from http://www.ojk.go.id/id/kanal/iknb/r egulasi/lembaga-keuanganmikro/peraturanojk/Documents/SAL-POJK PERIZINAN FINAL F.pdf

Putri, A. A. B., \& Sampurno, R. D. (2012). Analisis Pengaruh ROA, EPS, NPM, DER dan PBV Terhadap Return Saham. Diponegoro Business Review, 1, 111.

Santoso Singgih. (2012). Aplikasi SPSS pada Statistik Parametrik. Jakarta: PT. Elex Media Komputindo.

Setiawan, B. (2017). Perbandingan Kinerja Pasar Modal Syariah dan Konvensional: Suatu Kajian Empiris pada Pasar Modal Indonesia. Jurnal Ilmiah Ekonomi Global Masa Kini, 8 (1)(Juli 2017), 35-40.

Setyowati, H., \& Ningsih, R. (2016). Pengaruh Faktor Fundamental, Risiko Sistemis dan Ekonomi Makro Terhadap return Saham Syariah yang Tergabung di Jakarta Islamik Indek (JII) pada Periode 2010 - 2014. Jurnal Kajian Bisnis, 24(1), 54-70.

Sinaga, A. K., \& Triaryati, N. (2014). Pengaruh Faktor Fundamental dan Ekonomi Makro Terhadap Harga Saham. E-Jurnal Manajemen Universitas Udayana, 3, 14121426.

Sukirno Sadono. (2015). MAKROEKONOMI: Teori Pengantar (Ed.3 Cet.2). Jakarta: PT.Raja Grafindo Persada.
Supadi, D. B. P., \& M. Nuryanto Amin. (2014). Pengaruh Faktor Fundamental dan Risiko Sistemis Terhadap Return Saham Syariah. Media Riset Akuntansi, Auditing \& Informasi, 12 (1)(April 2012), 2345 .

Suyati, S. (2015). Pengaruh Inflasi, Tingkat Suku Bunga Dan Nilai Tukar Rupiah / Us Dollar Terhadap Return Saham Properti Yang Terdaftar di Bursa Efek Indonesia. Jurnal Ilmiah UNTAG Semarang, 4, 70-86.

Tandelilin Eduardus. (2010). Portofolio dan Investasi: Teori dan Aplikasi (1st ed.). Yogyakarta: Karnisius.

Yeye, S., \& Tri, T. (2011). Reaksi Signal Rasio Profitabilitas dan Rasio Solvabilitas Terhadap Return Saham Perusahaan. Dinamika Keuangan Dan Perbankan, 3 (1)(Mei 2011), 17-37.

\section{Website:}

https://www.bps.go.id/ diakses pada tanggal 5 September 2017

http://www.bi.go.id/id/moneter/inflasi/da ta/ diakses pada tanggal 5 September 2017

https://www.finance.yahoo.com diakses pada tanggal 6 September 2017

https://finance.google.com diakses pada tanggal 6 September 2017

http://www.idx.co.id/ diakses pada tanggal 7 September 2017

http://www.reuters.com/ diakses pada tanggal 7 September 2017. 